\title{
Using Expert Knowledge to Understand Biosecurity Adoption Aimed at Reducing Tier 1 Disease Risks in the U.S. Livestock Industry
}

\author{
Qianrong Wu ${ }^{1}$, Lee L. Schulz ${ }^{1} \&$ Glynn T. Tonsor ${ }^{2}$ \\ ${ }^{1}$ Department of Economics, Iowa State University, Ames, Iowa, USA \\ ${ }^{2}$ Department of Agricultural Economics, Kansas State University, Manhattan, Kansas, USA \\ Correspondence: Lee L. Schulz, Department of Economics, Iowa State University, 518 Farm House Lane, Ames, \\ IA 50011, USA. Tel: 1-515-294-3356. E-mail: 1schulz@iastate.edu
}

Received: September 28, 2017

Accepted: November 5, 2017

Online Published: December 15, 2017

doi:10.5539/jas.v10n1p12

URL: https://doi.org/10.5539/jas.v10n1p12

\begin{abstract}
Using primary data from a survey of swine, beef cattle, and dairy industry experts in the United States, this study provides insights into adoption of biosecurity measures aimed at reducing Tier 1 disease risks. Experts believe the swine industry would see the highest and the beef cattle industry would see the lowest biosecurity adoption in the first year of a large Tier 1 disease outbreak. Risk reduction has a positive marginal effect on biosecurity adoption, and a firm's own risk reduction matters as well as their closest neighbor's risk reduction. Costs have a negative marginal effect on biosecurity adoption. A key reason explaining partial adoption might be that experts believe industry-wide biosecurity investment would likely bring benefits primarily to downstream sectors in the supply chain and producers would bare most of the costs. More educational materials available to explain Tier 1 disease risks and the benefits of risk mitigating biosecurity measures is found to be the least important factor for adoption and implementation of new, additional biosecurity measures. A producer or neighbor having personally experienced a Tier 1 disease on their operation, a producer's view on their own likelihood of experiencing a Tier 1 disease given their current situation, and a producer's view on effectiveness in reducing Tier 1 disease risks are found to be the most important factors. Understanding how several factors might impact biosecurity adoption aimed at reducing Tier 1 disease risks is necessary for the development of practices and policies that could reduce the impact of such disease incursions.
\end{abstract}

Keywords: beef cattle, biosecurity, dairy, expert survey, foreign animal disease, risk reduction, swine

\section{Introduction}

Conceptually, biosecurity is easy to embrace. The goal is to avoid the entry of pathogens into a herd or farm (external biosecurity) and to prevent the spread of disease to uninfected animals within a herd or to other farms when the pathogen is already present (internal biosecurity) (FAO \& OIE, 2010, pp. viii-ix). Biosecurity adoption involves making resource allocation choices about low probability risks that may materialize in the indefinite future (Hennessy, 2008). However, difficulties arise in practical implementation, such as how to implement biosecurity within the economic constraints of livestock production.

Existing biosecurity plans offer protection against endemic diseases (Lewerin, Österberg, Alenius, Elvander, \& Fellström, 2015) but heightened safeguards are needed for foreign animal diseases. According to the National Animal Health Monitoring System Program, almost one-third (32.1\%) of beef cow-calf operations disagreed when asked if "The United States is well prepared to handle outbreaks of livestock disease currently not found in this country, such as foot-and-mouth disease and rinderpest" (USDA-APHIS-VS, 2010).

If a high-consequence foreign animal disease, hereafter referred to as a Tier 1 disease (NOTE 1), were to be introduced in the United States, the disruption would be significant, especially if the disease is not quickly identified and confined to a small area. Quickly culling and disposing of infected and potentially exposed animals, or stamping out, could be effective in the case of a small, confined Tier 1 disease outbreak. If a Tier 1 disease were to spread to multiple areas, a stamping-out strategy would become logistically and economically impractical. In that case, some combination of stamping out, biosecurity, vaccination, and slaughter of exposed animals would be needed (Roth \& Spickler, 2014). Of these, the only tool that is realistically currently available on a large scale is biosecurity (Roth \& Spickler, 2014). Enhanced biosecurity is a key component of the Secure 
Food Supply Plans (http://www.cfsph.iastate.edu/Secure-Food-Supply/) currently being designed to provide business continuity in the event of a foreign animal disease outbreak. While important, current understanding of many facets of biosecurity is limited, presenting knowledge gaps we begin to address here.

The main objective of this article is to examine prospective biosecurity adoption and compliance following a large Tier 1 disease outbreak in the United States. Our analysis involves forecasting how sensitive biosecurity adoption is to a firm's own risk reduction and a neighbor's risk reduction, and upfront implementation costs and annual maintenance costs. Identification of this sensitivity allows forecasting adoption rates under different scenarios. The relative importance of other factors impacting adoption and persistent compliance with biosecurity measures aimed at reducing Tier 1 disease risks are also provided. This study is the first known evaluation aimed at improving understanding of how risk reduction, costs, and other factors impact biosecurity adoption and compliance. Combined, these contributions help begin to fill several knowledge gaps around economic forces (Rushton, 2017) and the role of education (Peeler \& Otte, 2016) versus personal disease experience in biosecurity investment decisions.

\section{Materials and Methods}

Given the enormous uncertainty about Tier 1 disease outbreaks and the difficulty in measuring expected biosecurity adoption, we rely on a sample of experts, which has been successfully employed in other biosecurity research (Leger, Nardi, Simons, Adkin, Ru, Estrada-Pena, \& Stark, 2017). Livestock industry stakeholders are instrumental in communicating and implementing biosecurity measures, which Tago, Hammitt, Thomas, and Raboisson (2016) find reflective of the asymmetric flow of animal health information within the industry. During a Tier 1 disease outbreak, producers and their team of experts are responsible for protecting animals from infection, and Hernández-Jover, Gilmour, Schembri, Sysak, and Holyoake (2012) find that co-management and trust among stakeholders is crucial to their success in doing so.

\subsection{Questionnaire Design}

We used Qualtrics survey software (Qualtrics, Provo, UT) to develop our surveys, which were approved by the Kansas State University Committee for Research Involving Human Subjects (\#8132.1).

We designed three similar, nearly identical surveys for swine, beef cattle, and dairy industry experts. Each survey contained six questions of primary interest in this article. We present questions here as they were asked in the swine survey. Analogous questions were asked in the beef cattle and dairy surveys.

Question 1 was designed to estimate how sensitive biosecurity adoption would be to risk reduction. Specifically, this question was presented as:

$>$ Q1: What share of national adoption do you expect the U.S. swine industry would achieve in the first year of a large Tier 1 disease outbreak if a given biosecurity measure reduced a firm's own risk of a Tier 1 disease outbreak by X\% and reduced their closest neighbor's risk by Y\%?

Available answers to this question included $0 \%, 1-10 \%, 11-20 \%, 21-30 \%, 31-40 \%, 41-50 \%, 51-60 \%, 61-70 \%$, $71-80 \%, 81-90 \%$, and $91-100 \%$. Two dimensions of risk reduction were used. A firm's own risk reduction (X\%) and their closest neighbor's risk reduction ( $\mathrm{Y} \%$ ) were both presented as random variables from $0 \%$ to $100 \%$. These two representations of risk reduction were chosen because the probability that a producer's herd can become infected depends not only on self-protection but also protection of neighbors (Reeling \& Horan, 2014). Actions to protect against the entry of a disease into a region are strategic complements as the nature of spatial interactions matter (Hennessy, 2007a).

Question 2 was designed to estimate how sensitive biosecurity adoption would be to costs. Specifically, this question was presented as:

Q2: What share of national adoption do you expect the U.S. swine industry would achieve in the first year of a large Tier 1 disease outbreak if a given Tier 1 disease targeted biosecurity measure costs \$FC/operation in one-time, up-front implementation costs and \$VC/animal/operation/year in annual maintenance costs on the operation?

Available answers to this question included $0 \%, 1-10 \%, 11-20 \%, 21-30 \%, 31-40 \%, 41-50 \%, 51-60 \%, 61-70 \%$, $71-80 \%, 81-90 \%$, and $91-100 \%$. Two dimensions of costs were used. Fixed costs (\$FC) and variable costs (\$VC) were both presented as random variables. Fixed costs ranged from $\$ 1$ to $\$ 10000$ per operation and variable costs ranged from $\$ 1$ to $\$ 5$ per animal per operation per year. Biosecurity investments entail a mixture of fixed and variable costs. Fixed costs are costs that are independent of output. Variable costs are costs that vary with output. 
By including fixed and variable costs, economic tradeoffs can be considered and the relative influence of each for biosecurity adoption identified.

Biosecurity implementation depends not only on risk reduction and costs, but also on attitudes towards and motivations for undertaking/not undertaking disease prevention (Gilmour, Beilin, \& Sysak, 2011). Questions 3 and 4 were designed to compare the relative importance of a myriad of factors impacting biosecurity implementation and compliance. These questions were specifically presented as:

> Q3: How important are the following factors in a typical swine producer's decision to adopt and implement new, additional biosecurity measures aimed at reducing Tier 1 disease risks in the swine industry during the first year of a large outbreak?

> Q4: How important are the following factors in a typical swine producer's persistent compliance (e.g. rigorous, ongoing maintenance of effort over time) with biosecurity measures previously implemented for reducing Tier 1 disease risks in the swine industry $Z$ years after initial implementation?

These questions were asked with an importance scale response such that $0=$ not important to $100=$ utmost importance. Years after initial implementation $(Z)$ was presented randomly and ranged from 1 to 10 .

For questions 3 and 4, nine factors were evaluated including: (a) up-front fixed (one-time) monetary costs of implementation; $(b)$ ongoing (recurring) monetary costs of implementation (or remaining compliant); $(c)$ availability of (recurring for compliance) governmental cost-share to reduce out-of-pocket expense; $(d)$ producer's view on their own likelihood of experiencing a Tier 1 disease given their current situation; $(e)$ producer's view on effectiveness in reducing Tier 1 disease risks; $(f)$ producer having personally experienced a Tier 1 disease on their operation; $(g)$ producer having a neighbor who personally experienced a Tier 1 disease on their operation; $(h)$ producer having more educational materials available to explain Tier 1 disease risks and the benefits of risk mitigating biosecurity measures; and, $(i)$ governmental indemnity payment eligibility requiring evidence of implementing Tier 1 disease risk mitigating biosecurity measures. These factors are mentioned in many discussions of biosecurity adoption and compliance (Hennessy, 2007a, 2007b, 2008; Horan, Fenichel, Wolf, \& Gramig, 2010; Reeling \& Horan, 2014; Wu, Schulz, Tonsor, \& Smith, 2017).

Knowledge of these factors can help governing entities serve current efforts aimed at increasing biosecurity adoption as well as identify factors not currently being addressed but relatively important to adoption decisions, thus, enabling more efficient resource allocation.

Biosecurity adoption is an example of a private behavior that generates positive spillovers affecting the supply of a public good, that is, infectious disease prevention (Buchanan \& Kafoglis, 1963; Olson \& Zeckhauser, 1970; Reeling \& Horan, 2014). This makes it less clear who will benefit and who will pay for it in the supply chain. To gain corresponding expert insight, questions 5 and 6 were designed to help explain the perceived distribution of benefits and costs.

$>$ Q5: If biosecurity measures aimed at reducing Tier 1 disease risks were put in place industry-wide, how do you think the resulting benefits would be distributed through the pork industry's supply chain?

> Q6: If biosecurity measures aimed at reducing Tier 1 disease risks were put in place industry-wide, how do you think the resulting costs would be distributed through the pork industry's supply chain?

For questions 5 and 6, respondents were asked to allocate the percentage (summing to 100\%) each of the sectors would capture for benefits and incur for costs. Sectors of the pork industry's supply chain presented were sow/breeding, nursery, finishing, processors/packers, and retailers.

\subsection{Survey Procedure and Data Collection}

In March and April of 2016, we distributed our surveys through two partner organizations, the American Association of Swine Veterinarians (AASV) and the National Institute for Animal Agriculture (NIAA). The NIAA sent the survey URLs through an email list serve of 778 members, and AASV included survey URLs in their online newsletters, which were distributed to 1965 members. Three weeks after the surveys were sent, we requested that our partner organizations send reminder messages to potential participants. Participants were asked to complete the survey for the industry or industries they were most familiar with.

\subsection{Statistical Analysis}

Tobit models were used to estimate the relationship between biosecurity adoption and risk reduction and costs. More formally, Tobit models were estimated as follows: 


$$
\begin{array}{ll}
A_{i}^{*}=\beta^{\prime} \mathbf{X}+e_{i}, e_{i} \sim N\left[0, \sigma^{2}\right] & \text { if } 0<A_{i}^{*}<1 \\
A_{i}=0 & \text { if } 0=A_{i}^{*} \\
A_{i}=1 & \text { if } 1=A_{i}^{*}
\end{array}
$$

Where, $A_{i}^{*}$ is the share of national adoption of a Tier 1 disease targeted biosecurity measure in the first year of a large Tier 1 disease outbreak, $\beta$ represents a vector of parameters to be estimated, $\mathbf{X}$ is a vector of explanatory variables, and $e_{i}$ is a normally distributed error term (Greene, 2003).

The share of national biosecurity adoption in the survey took the values of $0 \%, 1-10 \%, 11-20 \%, 21-30 \%$, $31-40 \%, 41-50 \%, 51-60 \%, 61-70 \%, 71-80 \%, 81-90 \%$, and $91-100 \%$. For this analysis we used the midpoint of each of the ranges. The dependent variable, $A$, therefore took the values $0 \%, 5.5 \%, 15.5 \%, 25.5 \%, 35.5 \%, 45.5 \%$, $55.5 \%, 65.5 \%, 75.5 \%, 85.5 \%$, and $95.5 \%$. The independent variables included a firm's own risk reduction and closest neighbor's risk reduction for one model and fixed costs and variable costs for another model.

Sample means were used to summarize the importance of factors influencing a producer's decision to adopt and implement new, additional biosecurity measures aimed at reducing Tier 1 disease risks during the first year of a large outbreak. Similarly, for the importance of factors affecting a producer's persistent compliance with biosecurity measures previously implemented for reducing Tier 1 disease risks, we used sample means to summarize and compare the overall (1-10 years after initial implementation), near-term (1-3 years), medium-term (4-6 years), as well as long-term (7-10 years) periods. We also tested for differences in importance rankings for adoption of biosecurity measures during the first year of a Tier 1 disease outbreak and the average of 1 to 10 years after initial implementation.

To compare the allocation of benefits and costs in each sector of production if biosecurity measures aimed at reducing Tier 1 disease risks were put in place industry-wide, we used sample means and $t$-tests calculated using STATA (StataCorp LP, 2016).

\section{Results}

\subsection{Response Rate and Respondent Profile}

We received 190 survey responses (70 beef cattle, 65 dairy, and 55 swine). However, some participants only partially completed the survey. The observation numbers for each question of interest are listed in Tables 1 through 7 and Figure 1.

Survey responses from experts in their respective fields represented areas of the United States with the highest levels of production. Swine experts that completed our survey most commonly interact with producers from GA, IA, IL, IN, KS, MN, NC, NE, OH, OK, and TX. These states account for $84 \%$ of the hog inventory and nearly half $(48 \%)$ of the swine operations in the United States (USDA-NASS, 2014a). Beef cattle experts that completed our survey most commonly interact with producers from AL, AR, CA, CO, GA, IL, IA, KS, KY, MI, MS, MO, NE, ND, OH, OR, PA, TN, TX, VA, WA, and WY. These states represent $67 \%$ and $70 \%$ of the beef cow inventory and beef cow operations, respectively, as well as $84 \%$ and $63 \%$ of the cattle on feed inventory and cattle on feed operations in the United States, respectively (USDA-NASS, 2014a). Dairy industry experts that completed our survey most commonly interact with producers from AZ, CA, FL, IN, ID, MD, MI, MN, MO, NJ, NM, NY, OH, PA, TX, VA, VT, WA, and WI with these states accounting for $84 \%$ and $77 \%$ of U.S. dairy cow inventory and operations, respectively (USDA-NASS, 2014a).

Expert familiarity with production segments differs with each industry. Eighty-four percent of dairy industry experts responding to our survey most commonly interact with commercial operations, while the remaining $16 \%$ most commonly interact with non-commercial operations. Beef cattle industry experts responding to our survey most commonly interact with cow-calf operations $(79 \%)$, the remainder with feedlots, other operations, or stocker operations at $11 \%, 8 \%$, and $3 \%$, respectively. Farrow-finish and farrow-wean are the most common type of operation that the swine industry experts responding to our survey interact with ( $36 \%$ and $27 \%$, respectively), after which, other operations, wean-finish, and feeder-finish are most common at $24 \%, 9 \%$, and $3 \%$, respectively.

\subsection{Forecasts of Biosecurity Adoption}

Table 1 presents summary statistics for the values employed in the survey for a firm's own risk reduction and a neighbor's risk reduction, and upfront implementation costs and annual maintenance costs. Considerable variation was provided in the risk reduction values, ranging from roughly $0 \%$ to $100 \%$, allowing us to estimate how sensitive biosecurity adoption would be to risk reduction. Again, considerable variation was provided in the 
cost values allowing us to estimate how sensitive biosecurity adoption would be to fixed- and variable-cost impacts and the relative tradeoff between the two cost components.

Table 1. Summary statistics of survey variables for a firm's own risk reduction, closest neighbor's risk reduction, one-time, upfront implementation costs, and annual maintenance costs

\begin{tabular}{|c|c|c|c|}
\hline Survey Variable & Swine Industry & Beef Cattle Industry & Dairy Industry \\
\hline \multicolumn{4}{|c|}{ Firm's own risk reduction, $\%$} \\
\hline Number of observations & 39 & 48 & 43 \\
\hline Mean & $46 \%$ & $46 \%$ & $50 \%$ \\
\hline Standard deviation & $26 \%$ & $31 \%$ & $31 \%$ \\
\hline Minimum & $5 \%$ & $0 \%$ & $1 \%$ \\
\hline Maximum & $98 \%$ & $100 \%$ & $98 \%$ \\
\hline \multicolumn{4}{|c|}{ Closest neighbor's risk reduction, \% } \\
\hline Number of observations & 39 & 48 & 43 \\
\hline Mean & $57 \%$ & $56 \%$ & $51 \%$ \\
\hline Standard deviation & $28 \%$ & $32 \%$ & $31 \%$ \\
\hline Minimum & $6 \%$ & $0 \%$ & $3 \%$ \\
\hline Maximum & $100 \%$ & $100 \%$ & $99 \%$ \\
\hline \multicolumn{4}{|c|}{ One time, upfront implementation costs, \$loperation } \\
\hline Number of observations & 38 & 48 & 43 \\
\hline Mean & $\$ 5,317$ & $\$ 4,406$ & $\$ 3,799$ \\
\hline Standard deviation & $\$ 3,238$ & $\$ 2,799$ & $\$ 2,554$ \\
\hline Minimum & $\$ 247$ & $\$ 61$ & $\$ 331$ \\
\hline Maximum & $\$ 9,873$ & $\$ 9,883$ & $\$ 8,813$ \\
\hline \multicolumn{4}{|c|}{ Annual maintenance costs, \$lanimalloperation/year } \\
\hline Number of observations & 38 & 48 & 43 \\
\hline Mean & $\$ 2.97$ & $\$ 2.85$ & $\$ 3.14$ \\
\hline Standard deviation & $\$ 1.42$ & $\$ 1.46$ & $\$ 1.49$ \\
\hline Minimum & $\$ 1.00$ & $\$ 1.00$ & $\$ 1.00$ \\
\hline Maximum & $\$ 5.00$ & $\$ 5.00$ & $\$ 5.00$ \\
\hline
\end{tabular}

The mean response by experts giving a forecast of the share of national adoption of a Tier 1 disease targeted biosecurity measure in the first year of a large Tier 1 disease outbreak was the highest for the swine industry, lowest for the beef cattle industry, and intermediate for the dairy industry. Under mean presented levels (Table 1) of a firm's own risk reduction and their closest neighbor's risk reduction, the share of national adoption rates were forecast to be $65.8 \%, 56.0 \%$, and $47.2 \%$ in the swine, dairy, and beef cattle industries, respectively (Table 2). When considering mean levels of fixed and variable costs the forecasted share of national adoption was $56.0 \%, 48.8 \%$, and $36.3 \%$ in the swine, dairy, and beef cattle industries, respectively (Table 3).

Tables 2 and 3 also present the marginal effects for the share of national adoption with respect to risk reduction and costs. It is important to note that the marginal effects are interpreted at the mean, thus for the average producer within the industry. Risk reduction was found to have a positive marginal effect on national adoption across the swine, beef cattle, and dairy industries (Table 2). Interpretation of the marginal effect estimates reveals that for every additional percentage point of a firm's own risk reduction, experts forecast $0.25 \%$ higher adoption in the beef cattle industry of a Tier 1 disease targeted biosecurity measure in the first year of a large Tier 1 disease outbreak. Experts forecast $0.20 \%$ higher adoption in the dairy industry. The marginal effect on a firm's own risk reduction was not statistically significant for the swine industry responses. For every additional percentage point of a producer's closest neighbor's risk reduction, experts forecast $0.17 \%, 0.23 \%$, and $0.18 \%$ higher biosecurity adoption in the swine, beef cattle, and dairy industry, respectively. There was found to be no statistically significant difference in the marginal effects between a firm's own risk reduction and their closest neighbor's risk reduction within each industry. 
Table 2. Marginal effects of the Tobit model and share of national adoption expected in the first year of a large Tier 1 disease outbreak of a biosecurity measure that reduces a firm's own risk and their closest neighbor's risk

\begin{tabular}{llll}
\hline Variable & $\begin{array}{l}\text { Swine Industry } \\
\text { Marginal Effect } \\
\text { (Standard Error) }\end{array}$ & $\begin{array}{l}\text { Beef Cattle Industry } \\
\text { Marginal Effect } \\
\text { (Standard Error) }\end{array}$ & $\begin{array}{l}\text { Dairy Industry } \\
\text { Marginal Effect } \\
\text { (Standard Error) }\end{array}$ \\
\hline Firm's own risk reduction & 0.105 & $0.247^{* * *}$ & $0.196^{* *}$ \\
& $(0.093)$ & $(0.092)$ & $(0.096)$ \\
\hline Closest neighbor's risk reduction & $0.165^{*}$ & $0.234^{* * *}$ & $0.183^{*}$ \\
& $(0.087)$ & $(0.089)$ & $(0.093)$ \\
\hline $\mathrm{H}_{0}:$ Firm's own risk reduction = Closest neighbor's risk reduction & & \\
F-statistic & 0.24 & 0.01 & 0.01 \\
p-value & 0.629 & 0.914 & 0.918 \\
\hline National adoption, \% & 65.8 & 47.2 & 56.0 \\
Standard deviation & {$[18.28]$} & {$[25.04]$} & {$[24.39]$} \\
\hline Number of observations & 39 & 48 & 43 \\
\hline
\end{tabular}

Note. Estimated coefficient estimates are available upon request. Likelihood ratio test (parameters equal to zero) was $-165.930(p=0.108)$ for swine industry, $-216.344(p=0.003)$ for beef cattle industry, $-194.230(p=0.026)$ for dairy industry. Single, double, and triple asterisks $(*, * *, * *)$ indicate statistical significance at the $10 \%, 5 \%$, and $1 \%$ level, respectively.

Table 3. Marginal effects of the Tobit model and share of national adoption expected in the first year of a large Tier 1 disease outbreak of a biosecurity measure with varying one-time, upfront implementation costs and annual maintenance costs

\begin{tabular}{|c|c|c|c|}
\hline Variable & $\begin{array}{l}\text { Swine Industry } \\
\text { Marginal Effect } \\
\text { (Standard Error) }\end{array}$ & $\begin{array}{l}\text { Beef Cattle Industry } \\
\text { Marginal Effect } \\
\text { (Standard Error) }\end{array}$ & $\begin{array}{l}\text { Dairy Industry } \\
\text { Marginal Effect } \\
\text { (Standard Error) }\end{array}$ \\
\hline One time, up-front implementation costs & $\begin{array}{l}-0.0004 \\
(0.001)\end{array}$ & $\begin{array}{l}-0.002 * * \\
(0.001)\end{array}$ & $\begin{array}{l}-0.003 * * \\
(0.001)\end{array}$ \\
\hline Annual maintenance costs & $\begin{array}{l}-5.082 * * \\
(2.165)\end{array}$ & $\begin{array}{l}0.310 \\
(1.770)\end{array}$ & $\begin{array}{l}-1.403 \\
(2.003)\end{array}$ \\
\hline \multicolumn{4}{|c|}{$\mathrm{H}_{0}$ : One time, upfront implementation costs $=$ Annual maintenance costs } \\
\hline F-statistic & 5.69 & 0.03 & 0.49 \\
\hline p-value & 0.022 & 0.861 & 0.488 \\
\hline National adoption, $\%$ & 56.0 & 36.3 & 48.8 \\
\hline Standard deviation & [23.24] & [23.05] & [26.52] \\
\hline Number of observations & 38 & 48 & 43 \\
\hline
\end{tabular}

Note. Estimated coefficient estimates are available upon request. Likelihood ratio test (parameters equal to zero) was $-170.261(p=0.067)$ for swine industry, $-215.886(p=0.098)$ for beef cattle industry, $-198.301(p=0.042)$ for dairy industry. Single, double, and triple asterisks $(*, * *, * *)$ indicate statistical significance at the $10 \%, 5 \%$, and $1 \%$ level, respectively.

As expected, the marginal effects on fixed and variable costs on adoption were found to be negative (Table 3). For every additional $\$ 1000$ of one-time, upfront implementation cost, experts forecast $2 \%$ lower adoption in the beef cattle industry. This was slightly higher for the dairy industry responses at $3 \%$ lower adoption for every additional $\$ 1000$ of fixed cost. The marginal effect on fixed cost was not statistically significant for the swine industry responses. For every additional $\$ 1$ of annual maintenance costs, experts forecast $5.1 \%$ lower biosecurity adoption in the swine industry. The marginal effects on annual maintenance costs were not statistically significant for the beef cattle and dairy industry responses. For the swine industry, fixed and variable costs were found to have differing impact on biosecurity adoption. This may reflect the role of contractors and integrators in the swine industry as business arrangement may impact whom within the industry incurs fixed and variable costs associated with certain biosecurity investments. No statistically significant differences were found between fixed and variable costs in the beef cattle and dairy industry responses. 


\subsection{Relative Importance of Factors Affecting Biosecurity Adoption and Compliance}

Figure 1 displays expert opinions on the absolute and relative importance of nine factors to the adoption and implementation of new, additional biosecurity measures aimed at reducing Tier 1 disease risks in the first year of a large outbreak. It is in the form of a two-dimensional chart with nine factors represented by the node and scores represented on axes starting from the central point. The nine factors were identified as important, all above 50 on an importance scale where 0 is not important and 100 is of utmost importance. To summarize the common findings across the three industries, experts ranked a producer having personally experienced a Tier 1 disease on their operation, a producer having a neighbor who personally experienced a Tier 1 disease on their operation, a producer's view on their own likelihood of experiencing a Tier 1 disease given their current situation, and a producer's view on effectiveness in reducing Tier 1 disease risks as being the most important factors to adoption. More educational materials available to explain Tier 1 disease risks and the benefits of risk mitigating biosecurity measures was commonly ranked lowest in importance.

The importance rankings are almost identical between the beef cattle and dairy industries across the nine factors, except that ongoing (recurring) monetary costs of implementation was ranked higher in the beef cattle industry. The importance ranking of a producer's view on their own likelihood of experiencing a Tier 1 disease given their current situation and a producer's view on effectiveness in reducing Tier 1 disease risks are lower for both the beef cattle and dairy industries than for the swine industry; while the importance ranking of governmental indemnity payment eligibility requiring evidence of implementing Tier 1 disease risk mitigating biosecurity measures and availability of governmental cost-share to reduce out-of-pocket expense are lower for swine industry than beef cattle and dairy industries.

Tables 4, 5, and 6 show the importance rankings for adoption of biosecurity measures during the first year of a large Tier 1 disease outbreak and with respect to persistent compliance with biosecurity measures previously implemented for reducing Tier 1 disease risks. The importance rankings for persistent compliance are shown for the overall period (1-10 years after initial implementation), near-term (1-3 years), medium-term (4-6 years), and long-term ( $7-10$ years).

When comparing the importance rankings for adoption of biosecurity measures during the first year of a Tier 1 disease outbreak to the average of 1 to 10 years after initial implementation one common theme arises across all three industries. Up-front fixed (one-time) monetary costs of implementation was found to be ranked higher (means statistically different at the $5 \%, 10 \%, 5 \%$ level for the swine, beef cattle, and dairy industry responses, respectively) for adoption in the first year of a Tier 1 disease outbreak than to compliance in subsequent years. This is intuitive, as it is possible that a fixed cost may be a sunk cost. For example, any fixed expense incurred for a biosecurity measure could become a sunk cost if a producer stops complying with the biosecurity measure and the cost cannot be recovered. Since decision-making only affects the future course of business, sunk costs should be irrelevant in the decision-making process. This explains why up-front fixed (one-time) monetary costs of implementation would be more important to adoption in the first year of a Tier 1 disease outbreak than to compliance in subsequent years. 


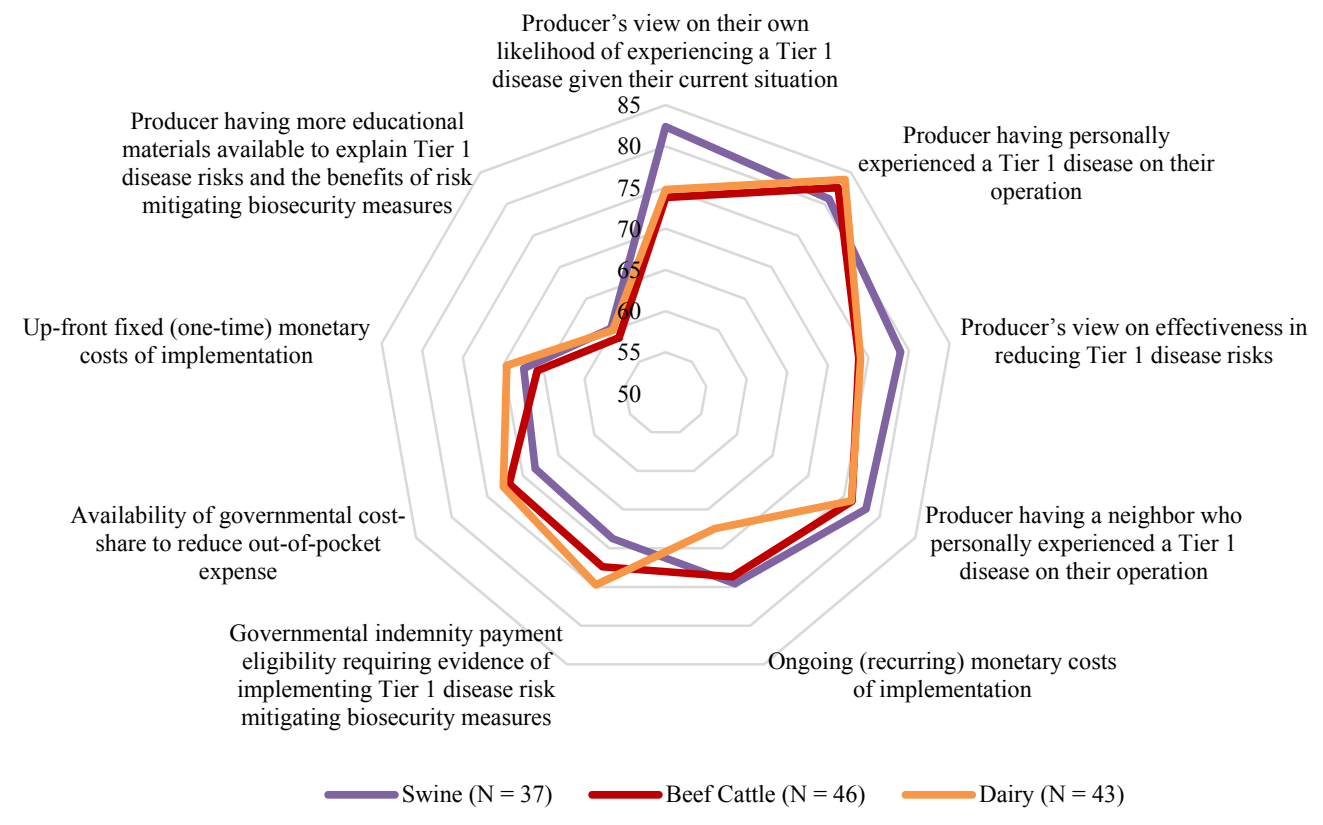

Figure 1. Experts' importance ranking of factors in a typical producer's decision to adopt and implement new, additional biosecurity measures aimed at reducing Tier 1 disease risks in the first year of a large outbreak

Note. Importance scale $(0=$ not important; $100=$ utmost importance). 
Table 4. Experts' importance ranking of factors in a typical swine producer's decision to adopt and comply with biosecuirty measures aimed at reducing Tier 1 disease risks

\begin{tabular}{|c|c|c|c|c|c|c|c|c|c|c|c|c|c|c|c|}
\hline \multirow{3}{*}{ Importance Ranking } & \multicolumn{3}{|c|}{$\begin{array}{l}\text { Implement new, } \\
\text { additional biosecurity } \\
\text { measures aimed at } \\
\text { reducing Tier } 1 \\
\text { disease risks }\end{array}$} & \multicolumn{12}{|c|}{$\begin{array}{c}\text { Persistent compliance (e.g. rigorous, ongoing maintenance of effort over time) } \\
\text { with biosecurity measures previously implemented } \\
\text { for reducing Tier } 1 \text { disease risks }\end{array}$} \\
\hline & \multicolumn{3}{|c|}{$\begin{array}{l}\text { First year of a } \\
\text { large outbreak }\end{array}$} & \multicolumn{3}{|c|}{$\begin{array}{l}\text { Overall } 1 \text { to } 10 \\
\text { years after initial } \\
\text { implementation }\end{array}$} & \multicolumn{3}{|c|}{$\begin{array}{l}\text { Near term } \\
1 \text { to } 3 \text { years } \\
\text { after initial } \\
\text { implementation }\end{array}$} & \multicolumn{3}{|c|}{$\begin{array}{l}\text { Medium term } \\
4 \text { to } 6 \text { years } \\
\text { after initial } \\
\text { implementation }\end{array}$} & \multicolumn{3}{|c|}{$\begin{array}{l}\text { Long term } \\
7 \text { to } 10 \text { years } \\
\text { after initial } \\
\text { implementation }\end{array}$} \\
\hline & $\mathrm{N}$ & Mean & $\begin{array}{l}\text { Std. } \\
\text { Dev. }\end{array}$ & $\mathrm{N}$ & Mean & $\begin{array}{l}\text { Std. } \\
\text { Dev. }\end{array}$ & $\mathrm{N}$ & Mean & $\begin{array}{l}\text { Std. } \\
\text { Dev. }\end{array}$ & $\mathrm{N}$ & Mean & $\begin{array}{l}\text { Std. } \\
\text { Dev. }\end{array}$ & $\mathrm{N}$ & Mean & $\begin{array}{l}\text { Std. } \\
\text { Dev. }\end{array}$ \\
\hline $\begin{array}{l}\text { Up-front fixed } \\
\text { (one-time) monetary } \\
\text { costs of implementation }\end{array}$ & 37 & $67.5^{\mathrm{a}}$ & 22.6 & 34 & $53.5^{\mathrm{a}}$ & 28.0 & 7 & 52.4 & 29.3 & 11 & 52.5 & 28.2 & 16 & 54.8 & 29.1 \\
\hline $\begin{array}{l}\text { Ongoing (recurring) } \\
\text { monetary costs of } \\
\text { implementation } \\
\text { (or remaining compliant) }\end{array}$ & 37 & 74.6 & 16.5 & 34 & 78.3 & 17.3 & 7 & 83.3 & 13.0 & 11 & 78.5 & 16.3 & 16 & 75.9 & 19.8 \\
\hline $\begin{array}{l}\text { Availability of (recurring } \\
\text { for compliance) } \\
\text { governmental } \\
\text { cost-share to reduce } \\
\text { out-of-pocket expense }\end{array}$ & 37 & 68.3 & 25.5 & 34 & 69.1 & 23.8 & 7 & 69.6 & 20.7 & 11 & 65.4 & 29.2 & 16 & 71.5 & 22.0 \\
\hline $\begin{array}{l}\text { Producer's view on } \\
\text { their own likelihood } \\
\text { of experiencing a Tier } 1 \\
\text { disease given their } \\
\text { current situation }\end{array}$ & 37 & 82.4 & 17.3 & 34 & 84.5 & 12.5 & 7 & 77.9 & 16.9 & 11 & 88.3 & 12.0 & 16 & 84.8 & 10.2 \\
\hline $\begin{array}{l}\text { Producer's view on } \\
\text { effectiveness in reducing } \\
\text { Tier } 1 \text { disease risks }\end{array}$ & 37 & 79.0 & 16.2 & 34 & 84.1 & 11.5 & 7 & 82.7 & 13.1 & 11 & 85.5 & 10.2 & 16 & 83.8 & 12.3 \\
\hline $\begin{array}{l}\text { Producer having } \\
\text { personally experienced } \\
\text { a Tier } 1 \text { disease } \\
\text { on their operation }\end{array}$ & 37 & 80.8 & 25.6 & 34 & 83.9 & 18.6 & 7 & 88.4 & 14.1 & 11 & 76.6 & 26.2 & 16 & 87.0 & 13.0 \\
\hline $\begin{array}{l}\text { Producer having a } \\
\text { neighbor who } \\
\text { personally experienced } \\
\text { a Tier } 1 \text { disease on } \\
\text { their operation }\end{array}$ & 37 & 78.1 & 15.6 & 34 & 73.0 & 18.6 & 7 & 73.9 & 21.9 & 11 & 75.8 & 23.1 & 16 & 70.6 & 14.2 \\
\hline $\begin{array}{l}\text { Producer having more } \\
\text { educational materials } \\
\text { available to explain } \\
\text { Tier } 1 \text { disease risks } \\
\text { and the benefits of risk } \\
\text { mitigating biosecurity } \\
\text { measures }\end{array}$ & 37 & 60.3 & 22.4 & 34 & 52.8 & 25.1 & 7 & 54.1 & 22.7 & 11 & 52.7 & 30.7 & 16 & 52.3 & 23.4 \\
\hline $\begin{array}{l}\text { Governmental indemnity } \\
\text { payment eligibility } \\
\text { requiring evidence } \\
\text { of implementing Tier } \\
1 \text { disease risk mitigating } \\
\text { biosecurity measures }\end{array}$ & 37 & 68.8 & 23.6 & 34 & 65.0 & 24.1 & 7 & 57.7 & 20.4 & 11 & 68.1 & 28.7 & 16 & 66.1 & 23.0 \\
\hline
\end{tabular}

Note. Importance scale $\left(0=\right.$ not important; $100=$ utmost importance) ${ }^{a}$ Means statistically different at the $5 \%$ level. 
Table 5. Experts' importance ranking of factors in a typical beef cattle producer's decision to adopt and comply with biosecuirty measures aimed at reducing Tier 1 disease risks

\begin{tabular}{|c|c|c|c|c|c|c|c|c|c|c|c|c|c|c|c|}
\hline \multirow{3}{*}{ Importance Ranking } & \multicolumn{3}{|c|}{$\begin{array}{l}\text { Implement new, } \\
\text { additional biosecurity } \\
\text { measures aimed at } \\
\text { reducing Tier } 1 \\
\text { disease risks }\end{array}$} & \multicolumn{12}{|c|}{$\begin{array}{l}\text { Persistent compliance (e.g. rigorous, ongoing maintenance of effort over time) } \\
\text { with biosecurity measures previously implemented } \\
\text { for reducing Tier } 1 \text { disease risks }\end{array}$} \\
\hline & \multicolumn{3}{|c|}{$\begin{array}{l}\text { First year of a } \\
\text { large outbreak }\end{array}$} & \multicolumn{3}{|c|}{$\begin{array}{l}\text { Overall } 1 \text { to } 10 \\
\text { years after initial } \\
\text { implementation }\end{array}$} & \multicolumn{3}{|c|}{$\begin{array}{l}\text { Near term } \\
1 \text { to } 3 \text { years } \\
\text { after initial } \\
\text { implementation }\end{array}$} & \multicolumn{3}{|c|}{$\begin{array}{l}\text { Medium term } \\
4 \text { to } 6 \text { years } \\
\text { after initial } \\
\text { implementation }\end{array}$} & \multicolumn{3}{|c|}{$\begin{array}{l}\text { Long term } \\
7 \text { to } 10 \text { years } \\
\text { after initial } \\
\text { implementation }\end{array}$} \\
\hline & $\mathrm{N}$ & Mean & $\begin{array}{l}\text { Std. } \\
\text { Dev. }\end{array}$ & $\mathrm{N}$ & Mean & $\begin{array}{l}\text { Std. } \\
\text { Dev. }\end{array}$ & $\mathrm{N}$ & Mean & $\begin{array}{l}\text { Std. } \\
\text { Dev. }\end{array}$ & $\mathrm{N}$ & Mean & $\begin{array}{l}\text { Std. } \\
\text { Dev. }\end{array}$ & $\mathrm{N}$ & Mean & $\begin{array}{l}\text { Std. } \\
\text { Dev. }\end{array}$ \\
\hline $\begin{array}{l}\text { Up-front fixed } \\
\text { (one-time) monetary } \\
\text { costs of implementation }\end{array}$ & 45 & $65.8^{\mathrm{b}}$ & 20.2 & 42 & $57.0^{\mathrm{b}}$ & 28.5 & 11 & 66.4 & 21.3 & 15 & 52.8 & 23.8 & 16 & 54.6 & 36.0 \\
\hline $\begin{array}{l}\text { Ongoing (recurring) } \\
\text { monetary costs } \\
\text { of implementation } \\
\text { (or remaining compliant) }\end{array}$ & 46 & 73.7 & 19.5 & 42 & 75.0 & 20.1 & 11 & 75.9 & 13.0 & 15 & 68.6 & 25.1 & 16 & 80.4 & 18.2 \\
\hline $\begin{array}{l}\text { Availability of (recurring } \\
\text { for compliance) } \\
\text { governmental } \\
\text { cost-share to reduce } \\
\text { out-of-pocket expense }\end{array}$ & 46 & 71.9 & 20.0 & 42 & 72.7 & 18.0 & 11 & 75.5 & 12.1 & 15 & 73.9 & 16.3 & 16 & 69.6 & 22.7 \\
\hline $\begin{array}{l}\text { Producer's view on } \\
\text { their own likelihood } \\
\text { of experiencing a Tier } 1 \\
\text { disease given their } \\
\text { current situation }\end{array}$ & 46 & 73.8 & 22.8 & 42 & 76.5 & 23.4 & 11 & 85.0 & 15.8 & 15 & 70.7 & 27.5 & 16 & 76.1 & 23.3 \\
\hline $\begin{array}{l}\text { Producer's view on } \\
\text { effectiveness in reducing } \\
\text { Tier } 1 \text { disease risks }\end{array}$ & 46 & 73.8 & 20.0 & 42 & 70.6 & 20.4 & 11 & 75.7 & 15.4 & 15 & 67.3 & 20.4 & 16 & 70.1 & 23.7 \\
\hline $\begin{array}{l}\text { Producer having } \\
\text { personally experienced } \\
\text { a Tier } 1 \text { disease } \\
\text { on their operation }\end{array}$ & 46 & 82.6 & 24.0 & 42 & 86.8 & 15.9 & 11 & 89.5 & 20.7 & 15 & 83.7 & 13.4 & 16 & 87.8 & 14.8 \\
\hline $\begin{array}{l}\text { Producer having a } \\
\text { neighbor who personally } \\
\text { experienced a Tier } 1 \\
\text { disease on } \\
\text { their operation }\end{array}$ & 46 & 76.1 & 19.1 & 42 & 72.4 & 20.7 & 11 & 77.8 & 26.4 & 15 & 70.9 & 17.8 & 16 & 70.1 & 19.5 \\
\hline $\begin{array}{l}\text { Producer having more } \\
\text { educational materials } \\
\text { available to explain } \\
\text { Tier } 1 \text { disease risks } \\
\text { and the benefits of } \\
\text { risk mitigating } \\
\text { biosecurity measures }\end{array}$ & 46 & 58.8 & 23.8 & 42 & 48.2 & 22.7 & 11 & 52.2 & 21.8 & 15 & 49.9 & 19.8 & 16 & 43.9 & 26.4 \\
\hline $\begin{array}{l}\text { Governmental indemnity } \\
\text { payment eligibility } \\
\text { requiring evidence } \\
\text { of implementing Tier } 1 \\
\text { disease risk mitigating } \\
\text { biosecurity measures }\end{array}$ & 46 & 72.4 & 21.2 & 42 & 72.3 & 20.3 & 11 & 78.9 & 14.7 & 15 & 74.7 & 19.6 & 16 & 65.6 & 23.1 \\
\hline
\end{tabular}

Note. Importance scale $(0=$ not important; $100=$ utmost importance $) .{ }^{\mathrm{b}}$ Means statistically different at the $10 \%$ level. 
Table 6. Experts' importance ranking of factors in a typical dairy producer's decision to adopt and comply with biosecuirty measures aimed at reducing Tier 1 disease risks

\begin{tabular}{|c|c|c|c|c|c|c|c|c|c|c|c|c|c|c|c|}
\hline \multirow{3}{*}{ Importance Ranking } & \multicolumn{3}{|c|}{$\begin{array}{l}\text { Implement new, } \\
\text { additional biosecurity } \\
\text { measures aimed at } \\
\text { reducing Tier } 1 \\
\text { disease risks }\end{array}$} & \multicolumn{12}{|c|}{$\begin{array}{l}\text { Persistent compliance (e.g. rigorous, ongoing maintenance of effort over time) } \\
\text { with biosecurity measures previously implemented } \\
\text { for reducing Tier } 1 \text { disease risks }\end{array}$} \\
\hline & \multicolumn{3}{|c|}{$\begin{array}{l}\text { First year of } \\
\text { a large outbreak }\end{array}$} & \multicolumn{3}{|c|}{$\begin{array}{l}\text { Overall } 1 \text { to } 10 \\
\text { years after initial } \\
\text { implementation }\end{array}$} & \multicolumn{3}{|c|}{$\begin{array}{l}\text { Near term } \\
1 \text { to } 3 \text { years } \\
\text { after initial } \\
\text { implementation }\end{array}$} & \multicolumn{3}{|c|}{$\begin{array}{l}\text { Medium term } \\
4 \text { to } 6 \text { years } \\
\text { after initial } \\
\text { implementation }\end{array}$} & \multicolumn{3}{|c|}{$\begin{array}{l}\text { Long term } \\
7 \text { to } 10 \text { years } \\
\text { after initial } \\
\text { implementation }\end{array}$} \\
\hline & $\mathrm{N}$ & Mean & $\begin{array}{l}\text { Std. } \\
\text { Dev. }\end{array}$ & $\mathrm{N}$ & Mean & $\begin{array}{l}\text { Std. } \\
\text { Dev. }\end{array}$ & $\mathrm{N}$ & Mean & $\begin{array}{l}\text { Std. } \\
\text { Dev. }\end{array}$ & $\mathrm{N}$ & Mean & $\begin{array}{l}\text { Std. } \\
\text { Dev. }\end{array}$ & $\mathrm{N}$ & Mean & $\begin{array}{l}\text { Std. } \\
\text { Dev. }\end{array}$ \\
\hline $\begin{array}{l}\text { Up-front fixed } \\
\text { (one-time) monetary } \\
\text { costs of implementation }\end{array}$ & 43 & $69.6^{\mathrm{a}}$ & 19.9 & 40 & $57.0^{\mathrm{a}}$ & 25.5 & 13 & 49.0 & 28.8 & 14 & 56.2 & 22.5 & 13 & 65.8 & 24.2 \\
\hline $\begin{array}{l}\text { Ongoing (recurring) } \\
\text { monetary costs of } \\
\text { implementation (or } \\
\text { remaining compliant) }\end{array}$ & 43 & 67.5 & 22.7 & 40 & 71.9 & 22.6 & 13 & 73.2 & 21.2 & 14 & 74.6 & 21.7 & 13 & 67.7 & 26.0 \\
\hline $\begin{array}{l}\text { Availability of (recurring } \\
\text { for compliance) } \\
\text { governmental } \\
\text { cost-share to reduce } \\
\text { out-of-pocket expense }\end{array}$ & 43 & 72.7 & 19.3 & 40 & 72.6 & 21.3 & 13 & 74.8 & 23.9 & 14 & 69.5 & 20.3 & 13 & 73.7 & 21.0 \\
\hline $\begin{array}{l}\text { Producer's view on } \\
\text { their own likelihood } \\
\text { of experiencing a Tier } 1 \\
\text { disease given their } \\
\text { current situation }\end{array}$ & 43 & 74.7 & 20.5 & 40 & 80.4 & 16.1 & 13 & 85.3 & 13.6 & 14 & 75.3 & 20.5 & 13 & 81.0 & 12.0 \\
\hline $\begin{array}{l}\text { Producer's view on } \\
\text { effectiveness in reducing } \\
\text { Tier } 1 \text { disease risks }\end{array}$ & 43 & 74.0 & 19.1 & 40 & 79.0 & 18.2 & 13 & 81.5 & 12.3 & 14 & 78.6 & 21.0 & 13 & 76.8 & 20.8 \\
\hline $\begin{array}{l}\text { Producer having } \\
\text { personally experienced } \\
\text { a Tier } 1 \text { disease } \\
\text { on their operation }\end{array}$ & 43 & 83.9 & 22.5 & 40 & 84.8 & 20.1 & 13 & 84.5 & 18.7 & 14 & 83.7 & 20.6 & 13 & 86.3 & 22.5 \\
\hline $\begin{array}{l}\text { Producer having a } \\
\text { neighbor who personally } \\
\text { experienced a Tier } 1 \text { disease } \\
\text { on their operation }\end{array}$ & 43 & 76.0 & 22.2 & 40 & 73.0 & 22.6 & 13 & 62.3 & 30.0 & 14 & 80.6 & 14.7 & 13 & 75.5 & 17.9 \\
\hline $\begin{array}{l}\text { Producer having more } \\
\text { educational materials } \\
\text { available to explain Tier } 1 \\
\text { disease risks and the } \\
\text { benefits of risk mitigating } \\
\text { biosecurity measures }\end{array}$ & 43 & 60.0 & 21.3 & 40 & 55.1 & 22.8 & 13 & 54.9 & 27.5 & 14 & 54.3 & 23.0 & 13 & 56.1 & 19.0 \\
\hline $\begin{array}{l}\text { Governmental indemnity } \\
\text { payment eligibility requiring } \\
\text { evidence of implementing } \\
\text { Tier } 1 \text { disease risk mitigating } \\
\text { biosecurity measures }\end{array}$ & 43 & 74.7 & 19.5 & 40 & 76.6 & 18.7 & 13 & 75.1 & 22.5 & 14 & 75.0 & 19.2 & 13 & 79.8 & 14.3 \\
\hline
\end{tabular}

Note. Importance scale $(0=$ not important; $100=$ utmost importance $){ }^{a}$ Means statistically different at the $5 \%$ level.

\subsection{Supply Chain Allocation of Benefits and Costs of Biosecurity Implementation}

Table 7 provides results of experts' perceptions concerning the allocation of benefits and costs industry-wide when implementing biosecurity measures aimed at reducing Tier 1 disease risks. 
Table 7. Expert views on resulting benefits and costs if biosecurity measures aimed at reducing Tier 1 disease risks were put in place industry-wide

\begin{tabular}{lllllll}
\hline Industry & Sector & $\mathrm{N}$ & Benefits, $\%$ & Costs, $\%$ & t-statistic & p-value \\
\hline Swine & Retailers & 33 & 13.1 & 3.9 & 3.40 & 0.002 \\
& Processors/Packers & 33 & 19.7 & 8.2 & 4.61 & 0.000 \\
& Finishing & 33 & 19.2 & 23.1 & -2.13 & 0.041 \\
& Nursery & 33 & 14.9 & 20.6 & -3.95 & 0.000 \\
& Sow/Breeding & 33 & 33.1 & 44.2 & -3.72 & 0.001 \\
\hline Beef Cattle & Retailers & 41 & 17.0 & 6.0 & 4.64 & 0.000 \\
& Processors/Packers & 41 & 18.0 & 10.7 & 3.58 & 0.001 \\
& Feedlot & 41 & 29.3 & 31.3 & -0.95 & 0.347 \\
& Stocker/Backgrounder & 41 & 16.9 & 22.8 & -4.93 & 0.000 \\
\cline { 6 - 6 } & Cow Calf & 41 & 18.9 & 29.2 & -4.41 & 0.000 \\
& Retailers & 38 & 20.1 & 9.1 & 4.44 & 0.000 \\
& Processors/Packers & 38 & 26.0 & 17.9 & 3.74 & 0.001 \\
& Dairy Producer & 38 & 53.9 & 73.1 & -5.52 & 0.000 \\
\hline
\end{tabular}

Experts believe most of the benefits are distributed somewhat evenly, whereas they believe costs are largely born by the live animal production segments. For each sector expected benefits and costs were significantly different except for feedlots in the beef cattle industry where experts think feedlots would capture roughly $30 \%$ of the benefits and incur roughly $30 \%$ of the costs if biosecurity measures aimed at reducing Tier 1 disease risks where put in place industry-wide. The significant gap between the benefits and costs for producers may outweigh Tier 1 disease risks, possibly perceived as low probability risks, in influencing producers' willingness to invest in biosecurity implementation.

\section{Discussion and Conclusion}

How livestock disease risk and biosecurity adoption is perceived is paramount to agricultural policy makers. We assessed biosecurity adoption aimed at reducing Tier 1 disease risks across three industries (swine, beef cattle, and dairy) in the United States using an expert-opinion survey. Two results are of particular importance. First, experts forecast national biosecurity adoption as limited in the livestock industries, mostly less than $50 \%$ in the first year of a large Tier 1 disease outbreak. Second, experts believe industry-wide biosecurity investment aimed at reducing Tier 1 disease risks would likely bring benefits primarily to downstream sectors in the supply chain and producers would bare most of the costs. Thus, the reason for "insufficient" biosecurity adoption may be rational decision making reflecting the fact that producers lack economic incentives to further adopt biosecurity measures. One possible solution could be the creation of additional economic incentives to producers so that the share of national adoption would increase and the whole supply chain would benefit more.

Past research has shown that biosecurity can be considered a public good best managed by the government (for reviews, see Horan et al., 2010). Our survey indicates that upstream private farms (live animal segments) lack strong incentives to make investments with broader, public good benefits. While, the downstream firms may also lack incentives for biosecurity investments because asymmetric information on sick animals and daily biosecurity measures could exist between the upstream private farms and other sectors in the supply chain. The economic incentives to the producers could be increased live animal values, improved market access terms, or enhanced government indemnity eligibility. Given connections to other aspects of production (Hennessey, Zhang, \& Bai, 2017), these possible adjustments warrant additional economic assessment and consideration.

This study also examines expert opinions on factors that affect biosecurity adoption. Results indicate biosecurity adoption is positively related to risk reduction and negatively related to costs. Wu et al. (2017) has shown that some under-implemented biosecurity measures are both highly effective (e.g., extent of risk reduction if implemented) and highly feasible (e.g., practicality of affordable implementation) for mitigating Tier 1 disease risks. Our survey indicates that one reason behind the low implementation of recommended biosecurity measures may be their corresponding costs. Other evidence driven by our results is that, especially in the case of the swine industry, firms may weigh fixed and variable costs differently when considering adopting biosecurity measures. Also, as expected, up-front fixed (one-time) monetary costs of implementation are found to be more important to biosecurity adoption in the first year than to compliance in subsequent years. One implication of this is targeting cost share programs towards fixed and variable costs differently for biosecurity adoption and compliance. 
Another important result is that firms care about their own risk reduction as well as their neighbor's risk reduction. During adverse events, past research suggests altruistic motives exist to help a neighbor reduce loss (Hoffman, 1981; Smith, 1986). At the same time, a producer might recognize that what helps their neighbor's operation also helps their own operation. A producer's view on the importance of own risk reduction and their neighbor's risk reduction is an important consideration for future research.

Results further suggest the swine industry would have the highest adoption of biosecurity measures in the first year of a large Tier 1 disease outbreak, and the beef cattle industry would have the lowest. The possible reasons behind the different forecasts of adoption across these industries are multifold. This ranking aligns with the rankings of animal density (measured by animal inventory within a geographic area) as the swine industry ranks the highest, dairy cattle industry in the middle, and beef cattle industry the lowest (USDA-NASS, 2014b). Not surprisingly, higher animal density creates greater disease risk and likely higher biosecurity adoption. Production and marketing structure may also determine how animal disease risks and economic incentives are shared across the supply chain. Among these three industries, the swine industry is the most vertical integrated, followed by the dairy industry, and the beef industry is the least integrated (National Research Council, 1999). A relatively small number of firms own and manage U.S. swine production, while a larger number of independent producers are involved in beef cattle and dairy production (Ward, 1997; Hayenga, Schroeder, Lawrence, Hayes, Vukina, Ward, \& Purcell, 2000; Miller, 2011). A more recent animal disease outbreak in the U.S. swine industry may also help explain why biosecurity adoption would be higher in the swine industry than beef cattle and dairy industries. The last major swine disease outbreak was porcine epidemic diarrhea virus in 2013-2014 and the last major cattle disease outbreak was bovine spongiform encephalopathy in 2003, and was an isolated incidence.

With respect to other factors impacting biosecurity adoption, a producer having personally experienced a Tier 1 disease on their operation, a producer having a neighbor who personally experienced a Tier 1 disease on their operation, a producer's view on their own likelihood of experiencing a Tier 1 disease given their current situation, and a producer's view on effectiveness in reducing Tier 1 disease risks are more important than a producer having more educational materials available to explain Tier 1 disease risks and the benefits of risk mitigating biosecurity measures. It is likely that producers see Tier 1 diseases as more probable if such experiences exist around them. However, it may be "too late" to adopt biosecurity measures when a larger Tier 1 disease has already occurred. Moore, Merryman, Hartman, and Klingborg (2008) reviewed over a hundred sources of published recommendations regarding biosecurity practices for various production animal species and classes. Our results suggest that the marginal benefits of additional educational materials may be low. This provides implications to researchers and educators that biosecurity education and outreach, provided in the same traditional manner, may not markedly improve biosecurity adoption.

\section{Acknowledgements}

This material is based upon work that is supported by the National Institute of Food and Agriculture, U.S. Department of Agriculture, under award number 2015-69004-23273.

\section{References}

Buchanan, J. M., \& Kafoglis, M. Z. (1963). A note on public goods supply. American Economic Review, 53, 403-14.

Food and Agriculture Organization of the United Nations/World Organization for Animal Health/World Bank. (2010). Good practices for biosecurity in the pig sector-Issues and options in developing and transition countries. FAO Animal Production and Health Paper No. 169. Rome, FAO.

Gilmour J., Beilin, R., \& Sysak, T. (2011). Biosecurity risk and peri-urban landholders-Using a stakeholder consultative approach to build a risk communication strategy. Journal of Risk Research, 14(3), 281-295. http://dx.doi.org/10.1080/13669877.2010.528560

Greene, W. (2003). Econometric analysis. Upper Saddle River, NJ: Prentice Hall.

Hayenga, M., Schroeder, T., Lawrence, J., Hayes, D., Vukina, T., Ward, C., \& Purcell, W. (2000). Meat packer vertical integration and contract linkages in the beef and pork industries: An economic perspective. American Meat Institute.

Hennessy, D. A. (2007a). Biosecurity and spread of an infectious animal disease. American Journal of Agricultural Economics, 89(5), 1226-1231. https://doi.org/10.1111/j.1467-8276.2007.01088.x 
Hennessy, D. A. (2007b). Behavioral incentives, equilibrium endemic disease, and health management policy for farmed animals. American Journal of Agricultural Economics, 89(3), 698-711. https://doi.org/10.1111/ j.1467-8276.2007.01001.x

Hennessy, D. A. (2008). Economic aspects of agricultural and food biosecurity. Biosecurity and Bioterrorism: Biodefense Strategy, Practice, and Science, 6(1), 66-77. https://doi.org/10.1089/bsp.2007.0016

Hennessy, D. A., Zhang, J., \& Bai, N. (2017). Animal health inputs, endogenous risk, general infrastructure, technology adoption and industrialized animal agriculture. Food Policy, in press. https://oi.org/10.1016/ j.foodpol.2017.08.022

Hernández-Jover, M., Gilmour, J., Schembri, N., Sysak T., \& Holyoake, P. K. (2012). Use of stakeholder analysis to inform risk communication and extension strategies for improved biosecurity amongst small-scale pig producers. Preventative Veterinary Medicine, 104, 258-270. https://doi.org/10.1016/j.prevetmed.2011. 12.006

Hoffman, M. L. (1981). Is altruism part of human nature? Journal of Personality and social Psychology, 40(1), 121. https://doi.org/10.1037/0022-3514.40.1.121

Horan, R. D., Fenichel, E. P., Wolf, C. A., \& Gramig, B. M. (2010). Managing infectious animal disease systems. Annual Review of Resource Economics, 2, 101-124. https://doi.org/10.1146/annurev.resource.012809. 103859

Leger, A., Nardi, M. D., Simons, R., Adkin, A., Ru, G., Estrada-Pena, A., \& Stark, K. D. C. (2017). Assessment of biosecurity and control measures to prevent incursion and to limit spread of emerging transboundary animal diseases in Europe: An expert survey. Vaccine, 35(44), 5956-5966. https://oi.org/10.1016/ j.vaccine.2017.07.034

Lewerin, S. S., Österberg, J., Alenius, S., Elvander, M., \& Fellström, C. (2015). Risk assessment as a tool for improving external biosecurity at farm level. BMC Veterinary Research, 11, 171-181. https://doi.org/ 10.1186/s12917-015-0477-7

Miller, T. (2011). Facts and myths of vertical integration. Pork Network. Retrieved May 7, 2017, from http://www.porknetwork.com/pork-magazine/facts-and-myths-of-vertical-integration-114003759.html

Moore, D. A., Merryman, M. L., Hartman, M. L., \& Klingborg, D. J. (2008). Comparison of published recommendations regarding biosecurity practices for various production animal species and classes. Journal of the American Veterinary Medical Association, 233(2), 249-256. https://doi.org/10.2460/javma.233.2.249

National Research Council. (1999). The use of drugs in food animals: Benefits and risks. National Academies Press.

Olson, M. Jr., \& Zeckhauser, R. (1970). The efficient production of external economies. American Economic Review, 60, 512-517. Retrieved from http://www.jstor.org/stable/1818010

Peeler, E. J., \& Otte, M. J. (2016). Epidemiology and economics support decisions about freedom from aquatic animal disease. Transboundary and Emerging Diseases, 63, 266-277. https://doi.org/10.1111/tbed.12278

Reeling, C. J., \& Horan, R. D. (2014). Self-protection, strategic interactions, and the relative endogenity of disease risks. American Journal of Agricultural Economics, 97(2), 452-468. https://oi.org/10.1093/ ajae/aau106

Roth, J. A., \& Spickler, A. R. (2014). FMD Vaccine Surge Capacity for Emergency Use in the United States. Veterinary Microbiology and Preventive Medicine Reports (Paper 8). Retrieved January 24, 2017, from http://lib.dr.iastate.edu/vmpm_reports/8

Rushton, J. (2017). Improving the use of economics in animal health-Challenges in research, policy and education. Preventive Veterinary Medicine, 137, 130-139. https://doi.org/10.1016/j.prevetmed.2016.11.020

Smith, R. J. F. (1986). Evolution of alarm signals: Role of benefits of retaining group members or territorial neighbors. The American Naturalist, 128(4), 604-610. https://doi.org/10.1086/284591

Tago, D., Hammitt, J. K., Thomas, A., \& Raboisson, D. (2016). The impact of farmer's strategic behavior on the spread of animal infectious diseases. Plos ONE, 11(6), e0157450. https://doi.org/10.1371/journal. pone. 0157450

U.S. Department of Agriculture, Animal and Plant Health Inspection Service, Veterinary Services (USDA-APHIS-VS). (2010). Beef 2007-08, Part IV reference of beef cow-calf management practices in the 
United States. Retrieved January 24, 2017, from https://www.aphis.usda.gov/animal_health/nahms/ beefcowcalf/downloads/beef0708/Beef0708_dr_PartIV.pdf

U.S. Department of Agriculture, Animal and Plant Health Inspection Service, Veterinary Services (USDA-APHIS-VS). (2013). High-Consequence Foreign Animal. Retrieved January 24, 2017, from https://www.aphis.usda.gov/publications/animal_health/2013/fs_hc_diseases.pdf

U.S. Department of Agriculture, National Agricultural Statistics Service (USDA-NASS). (2014a). 2012 census of agriculture, United States summary and state data. Retrieved January 24, 2017, from http://www.agcensus.usda.gov/Publications/2012/Full_Report/Volume_1,_Chapter_1_US/usv1.pdf

U.S. Department of Agriculture, National Agricultural Statistics Service (USDA-NASS). (2014b). 2012 Census Ag Atlas Maps-Livestock and Animals. Retrieved May 8, 2017, from https://www.agcensus.usda.gov/ Publications/2012/Online_Resources/Ag_Atlas_Maps/Livestock_and_Animals

Ward, C. E. (1997). Vertical integration comparison: Beef, pork, and poultry. 1997 Annual Meeting, July 13-16, 1997, Reno/Sparks, Nevada (No. 35759). Western Agricultural Economics Association.

Wu Q., Schulz, L. L., Tonsor, G. T., \& Smith, J. M. (2017). Expert views on effectiveness, feasibility, and implementation of biosecurity measures for mitigating tier 1 disease risks in the U.S. swine, beef cattle, and dairy industries. Journal of Veterinary Science and Technology, 8, 435. https://doi.org/10.4262/ 2157-7579.1000435

\section{Notes}

Note 1. Tier 1 diseases (African swine fever, classical swine fever, foot-and-mouth disease, avian influenza, and virulent Newcastle disease) are of national concern as they have the highest risks and consequences and pose the most significant threat to animal agriculture in the United States (USDA-APHIS-VS, 2013).

\section{Copyrights}

Copyright for this article is retained by the author(s), with first publication rights granted to the journal.

This is an open-access article distributed under the terms and conditions of the Creative Commons Attribution license (http://creativecommons.org/licenses/by/4.0/). 